\title{
THE GLUCAGON CONTENT OF CRYSTALLINE INSULIN PREPARATIONS
}

\author{
By A. STAUB ANd OTTO K. BEHRENS with the technical assistance of J. T. ELLIS \\ AND R. W. KENNEDY
}

(From the Lilly Research Laboratories, Indianapolis, Ind.)

(Submitted for publication July 12, 1954 ; accepted August 5, 1954)

Shortly after the discovery of insulin, investigators reported that intravenous administration of this hormone leads to a transient hyperglycemia. Kimball and Murlin (1) suggested that this response was caused by the presence of a second physiologically active substance which they named glucagon. Some workers $(2,3)$, however, suggested that this effect might be ascribed to insulin, or possibly to an artifact created during the manufacture of insulin (4). Considerable evidence accumulated during the last decade favors the view that the short initial hyperglycemia observed following administration of insulin preparations, is due to the presence of small quantities of a second active substance, probably secreted by the $\alpha$-cells of the pancreatic islets. The successful isolation of the hyperglycemic principle in highly purified and crystalline form (5) furnished conclusive proof that the factor is indeed an entity different from insulin. The amino acid composition of the crystalline material differs significantly from that of insulin (6). Available evidence indicates that the two proteins also differ in regard to their physico-chemical properties. Hence, it appears unlikely that difficulties in separating glucagon from insulin are due to similar chemical or physico-chemical properties as concluded by Bürger and Brandt (7). Although most of the hyperglycemic principle is removed from insulin in the course of its purification, small amounts can be found in most purified preparations. Many of these have been described as homogeneous on the basis of physico-chemical evidence (8). However, more recent work, based on counter current distribution (9), electrophoresis (10), and electrophoresis convection (11), have suggested the presence of some heterogeneity in crystalline insulin preparations. Small amounts of glucagon might partly account for these findings. Several authors have attempted to estimate the glucagon content of various crystal- line insulin preparations $(10,12-14)$. These estimates, ranging from 1 to 10 per cent, have been obtained by indirect or at best semi-quantitative methods and must be regarded as tentative. The uncertainty of these results prompted the present quantitative study of the glucagon content of crystalline insulin samples. For this purpose the hyperglycemic activity of a number of different insulin preparations was compared with that of reference samples consisting of glucagon-free insulin to which known amounts of crystalline glucagon had been added. The results of these experiments are described in this paper.

\section{BIOLOGICAL ASSAY}

The method for measuring the biological activity of glucagon is based on the hyperglycemic response in cats (15). This animal was selected because of its high sensitivity and comparatively constant response. Interference by the hypoglycemic action of insulin during the biological assay was prevented by incubating the samples with cysteine. This procedure destroys insulin activity but has no effect on the glucagon.

Starved cats (16 to 18 hours) weighing 2500 to 3000 grams were anesthetized by intraperitoneal injection of 70 to $80 \mathrm{mg}$. of Amytal Sodium (Amobarbital Sodium, Lilly) per $\mathrm{Kg}$. After 30 minutes the femoral vein was exposed in both legs. One vein was used for injection of the test solution (administered in a volume of $0.05 \mathrm{ml}$. per $\mathrm{Kg}$.) and the other for blood sampling. A control blood sample was collected before injection of the test solution; additional samples were withdrawn at five-minute intervals during 25 minutes. Blood sugar was determined according to the method of Somogyi (16).

Administration of increasing quantities of glucagon produces a proportional elevation of the blood sugar level until a maximum response is obtained. Larger doses have no additional effect on the net elevation of the blood sugar but cause a prolongation of the hyperglycemia. The maximum response in the cat, a blood sugar increase of approximately $100 \mathrm{mg}$. per cent, is ob- 


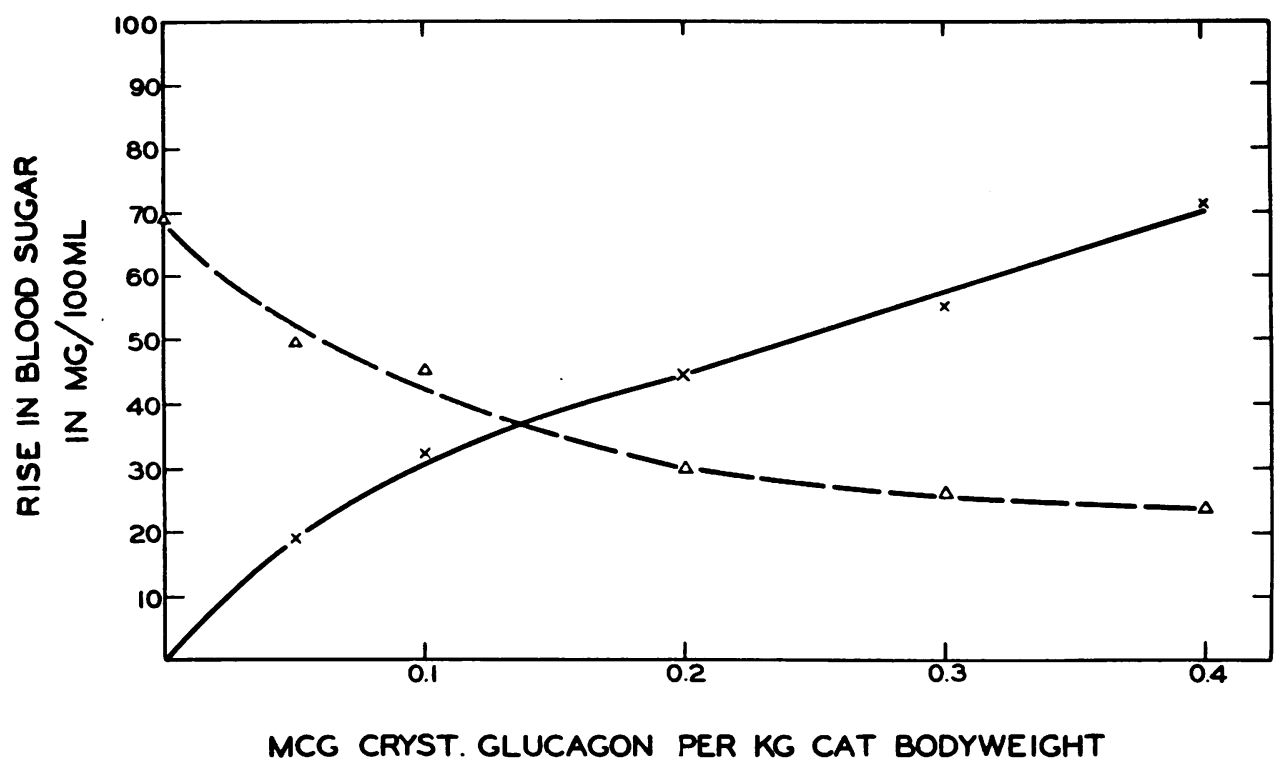

Fig. 1. Fffect of Increasing Doses of Glucagon on the Blood Sugar Level and the STANDARD Response

$-\times-\times-\begin{aligned} & \text { Maximum rise in blood sugar caused by crystalline glucagon (first } \\ & \text { injection). }\end{aligned}$
$-\triangle-\triangle-\begin{aligned} & \text { Maximum hyperglycemia caused by the standard injected } 25 \text { minutes } \\ & \text { after administration of the crystalline glucagon. }\end{aligned}$

tained by intravenous injection of 1 to $2 \mathrm{mcg}$. per $\mathrm{Kg}$. of crystalline glucagon.

Figure 1 shows the increase in blood sugar as a function of the glucagon dose. Experience has shown that greatest reproducibility is obtained in the range below half maximum response. For this reason the protein concentration of the test dose was adjusted so that the blood sugar rise was within the limits of 20 to $50 \mathrm{mg}$. per cent. Under these conditions maximum hyperglycemia occurs between 10 and 15 minutes following injection.

The standard deviations of column 3 in Table II show that the net blood sugar increase, caused by a given dose of glucagon, varies within relatively wide limits. A typical example of the variation in sensitivity that may be expected is given in Table I.

Information about the sensitivity of each particular animal is gained by injecting a standard preparation of known potency immediately following the first 25-minute interval. Since the hyperglycemic peak again occurs between 10 and 15 minutes following injection, the second half of the test need not be extended beyond $15 \mathrm{~min}$ - utes. Column 2 in Table I shows that the blood sugar rise caused by the standard varies approximately in proportion to the rise obtained by the sample injected initially. This makes it possible largely to eliminate the variable due to sensitivity

TABLE I

Variation of blood sugar in cats in response to a given dose of glucagon

\begin{tabular}{|c|c|c|}
\hline \multirow[b]{2}{*}{$\begin{array}{l}\text { Cat } \\
\text { No. }\end{array}$} & \multicolumn{2}{|c|}{$\begin{array}{c}\text { Maximum rise in blood sugar in } \\
m \mathrm{mg} \text {. per } 100 \mathrm{ml} .\end{array}$} \\
\hline & $\begin{array}{l}\text { First injection } \\
0.05 \text { mcg. } \\
\text { cryst. glucagon } \\
\text { per Kg. }\end{array}$ & $\begin{array}{c}\text { Second injection } \\
0.05 \mathrm{ml} \text {. } \\
\text { of standard } \\
\text { per } \mathrm{Kg} .\end{array}$ \\
\hline 1 & 9.1 & 36.2 \\
\hline 2 & 22.6 & 66.7 \\
\hline 3 & 11.3 & 49.8 \\
\hline 4 & 20.3 & 55.3 \\
\hline 5 & 22.6 & 75.7 \\
\hline 6 & 28.3 & 44.6 \\
\hline 7 & 24.3 & 50.3 \\
\hline 8 & 18.6 & 49.7 \\
\hline 9 & 11.8 & 45.8 \\
\hline 10 & 10.2 & 23.2 \\
\hline 11 & 11.8 & 43.5 \\
\hline 12 & 4.5 & 17.3 \\
\hline 13 & 30.0 & 79.6 \\
\hline
\end{tabular}

* The standard is injected immediately after withdrawal of the 25-minute blood sample. It is equivalent to 0.2 mcg. crystalline glucagon per $\mathrm{Kg}$. 
TABLE II

Response ratio to glucagon in cats as a function of increasing dosage

\begin{tabular}{|c|c|c|c|c|}
\hline \multirow{2}{*}{$\begin{array}{l}\text { Cryst. } \\
\text { glucagon } \\
\text { in first } \\
\text { injection } \\
(m c g . / K g .)\end{array}$} & \multirow{2}{*}{$\begin{array}{l}\text { Number } \\
\text { of } \\
\text { observa- } \\
\text { tions }\end{array}$} & \multicolumn{2}{|c|}{ Rise in blood sugar ( $m g . / 100 \mathrm{ml}$. ) } & \multirow[b]{2}{*}{ Response ratio } \\
\hline & & $\begin{array}{l}\text { First injection } \\
\text { Test dose }\end{array}$ & $\begin{array}{c}\text { Second injection } \\
\text { Standard }^{*}\end{array}$ & \\
\hline $\begin{array}{l}0.05 \\
0.10 \\
0.20 \\
0.30 \\
0.40 \\
5.0 \\
15.0\end{array}$ & $\begin{array}{r}14 \\
12 \\
12 \\
13 \\
21 \\
4 \\
8\end{array}$ & $\begin{array}{l}19.1 \pm 10.22 \dagger \\
32.0 \pm 10.2 \\
44.5 \pm 15.5 \\
55.0 \pm 20.6 \\
71.0 \pm 19.9 \\
155 \pm 22.3 \\
100 \pm 13.5\end{array}$ & $\begin{array}{l}49.6 \pm 17.2 \dagger \\
45.4 \pm 12.0 \\
30.0 \pm 8.9 \\
26.0 \pm 10.1 \\
24.0 \pm 9.6 \\
0 \\
0\end{array}$ & $\begin{array}{l}0.38 \pm 0.040 \ddagger \\
0.72 \pm 0.065 \\
1.53 \pm 0.131 \\
2.13 \pm 0.131 \\
2.95 \pm 0.228 \\
\text { Indeterminate } \\
\text { Indeterminate }\end{array}$ \\
\hline
\end{tabular}

* Glucagon equivalent to $0.2 \mathrm{mcg} . / \mathrm{Kg}$. of crystalline preparation.

t Standard deviation.

$\ddagger$ Standard error of the mean.

differences of the individual animals. Instead of using the net blood sugar rise as a measure for activity, it is advantageous to use the quotient, obtained by dividing the net maximum increase following injection of the sample by the net maximum rise caused by the standard preparation during the second test period. This quotient or response ratio improves the accuracy of the test considerably. It can be seen from column 4 in Table II that the standard error of the mean does not exceed 10 per cent for any of the samples investigated. The effect of an appropriate constant dose of the standard preparation depends to some degree on the magnitude of the hyperglycemia produced by the first injection. The broken curve in Figure 1 clearly illustrates the inverse relationship between sample and standard response. The latter decreases to zero as the response to the first injection reaches its maximum following a dose of 1 to $2 \mathrm{mcg}$. of crystalline

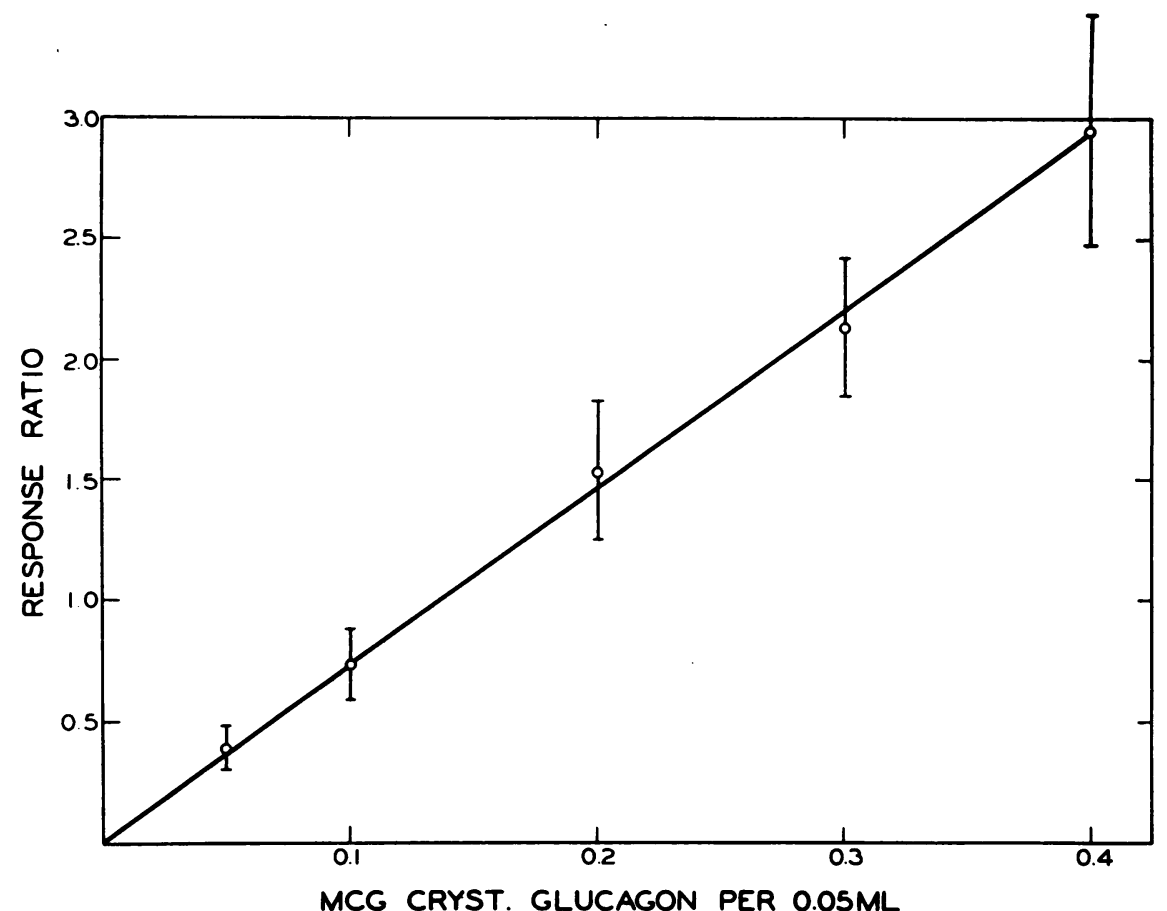

Fig. 2. Dosage Response Ratio Curve

The standard preparation used was equivalent to a solution containing $4 \mathrm{mcg}$. of crystalline glucagon per $\mathrm{ml}$. 
glucagon per $\mathrm{Kg}$. The numerical values of the quotients, as well as their fiducial limits increase rapidly in the region of maximum hyperglycemia. This region, therefore, is not suitable for measurements of activity. As pointed out earlier, the first response should be limited to 20 to $50 \mathrm{mg}$. per cent. The dosage-response ratio curve in this range is a linear function as is shown in Figure 2. The slope of the straight line is a function of the potency of the standard preparation. The standard used in these experiments was equivalent to a solution of $4 \mathrm{mcg}$. of crystalline glucagon per $\mathrm{ml}$.

\section{EXPERIMENTAL PROCEDURE}

A number of crystalline insulin preparations have been tested for their content of hyperglycemic factor.

\section{Preparation of samples}

Six mg. of crystalline $\mathrm{Zn}$-insulin were dissolved in approximately $2 \mathrm{ml}$. of dilute acid and the $\mathrm{pH}$ was adjusted to 7.5 with 0.2 per cent sodium hydroxide. The volume was brought to $10 \mathrm{ml}$. after addition of $3.5 \mathrm{ml}$. of a one per cent cysteine solution of $\mathrm{pH} 7.5$. The mixture was incubated for 16 hours at 18 to $23^{\circ} \mathrm{C}$. This incubation period is sufficient to destroy most of the insulin activity.

The response ratios were determined as described above, injecting $0.05 \mathrm{ml}$. of incubated mixture per $\mathrm{Kg}$. cat body weight. The protein concentration of the samples was adjusted so that the usual dose administered yielded a response ratio close to 0.8 or 1.6. These were the ratios obtained with similarly treated glucagonfree insulin preparations to which 0.3 and 0.6 per cent by weight of crystalline glucagon had been added. The glucagon-free insulin used for these experiments was a special preparation, lot No. 208-158B-238, having a potency of $24.4 \mu$ per mg. It was essentially free of glucagon, since administration of 33 to $600 \mathrm{mcg}$. per $\mathrm{Kg}$. body weight did not cause any rise in blood sugar.

\section{RESULTS AND DISCUSSION}

The analytical data for the different preparations are summarized in Table III. The dose of crystalline glucagon administered by injecting the glucagon-containing reference samples was 0.1 and $0.2 \mathrm{mcg}$. per $\mathrm{Kg}$. cat body weight, respectively. The response ratios of these samples are, within the limit of error, identical with the ones obtained by administering identical amounts of crystalline glucagon alone. It appears therefore that the other components of the incubation mixture have no effect on the glucagon activity. Hence, use was made of the dosage response ratio curve to compute the glucagon content of samples. Response ratios ranging from 0.7 to 1.7 yield the most reproducible portion of the curve. For this reason only assays with ratios within this range have been considered. The results summarized in Table III indicate that a number of samples of crystalline $\mathrm{Zn}$-insulin have a glucagon content of approximately 0.3 to 0.5 per cent. It seems unlikely that this small quantity can be detected by most physico-chemical methods. Therefore, the presence of glucagon does not offer an adequate explanation for the heterogeneities reported in insulin preparations.

In a recent paper, Root, Ellis, and Staub (17) have presented evidence that addition of glucagon

TABLE III

Determination of glucagon content of crystalline insulin samples

\begin{tabular}{|c|c|c|c|c|c|}
\hline Preparation & $\begin{array}{l}\text { mcg. } \\
\text { Protein per } \\
\text { Kg. cat }\end{array}$ & $\begin{array}{c}\text { Number } \\
\text { of } \\
\text { animals }\end{array}$ & $\begin{array}{l}\text { Mean response } \\
\text { ratio }\end{array}$ & 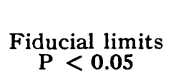 & $\begin{array}{c}\% \text { Glucagon in } \\
\text { preparation }\end{array}$ \\
\hline $\begin{array}{l}\text { Glucagon-free insulin } \\
+0.3 \% \text { glucagon } \\
\text { Glucagon-free insulin }\end{array}$ & 30 & 19 & $0.797 \pm 0.055^{*}$ & $0.685-0.909$ & 0.3 \\
\hline$+0.6 \%$ glucagon & 30 & 14 & $1.65 \pm 0.109$ & $1.416-1.884$ & 0.6 \\
\hline $\begin{array}{r}\text { Cryst. Zn insulin } \\
\text { A } \\
\text { B } \\
\text { C } \\
\text { D } \\
\text { E } \\
\text { ML535664 }\end{array}$ & $\begin{array}{l}30 \\
30 \\
30 \\
30 \\
30 \\
30\end{array}$ & $\begin{array}{l}14 \\
15 \\
18 \\
18 \\
18 \\
14\end{array}$ & $\begin{array}{l}0.741 \pm 0.056 \\
0.775 \pm 0.079 \\
0.902 \pm 0.066 \\
1.02 \pm 0.078 \\
0.88 \pm 0.071 \\
1.15 \pm 0.11\end{array}$ & $\begin{array}{l}0.620-0.862 \\
0.607-0.943 \\
0.764-1.04 \\
0.887-1.153 \\
0.731-1.029 \\
0.914-1.386\end{array}$ & $\begin{array}{l}0.33 \pm 0.10 \dagger \\
0.35 \pm 0.11 \\
0.41 \pm 0.11 \\
0.46 \pm 0.13 \\
0.40 \pm 0.11 \\
0.52 \pm 0.15\end{array}$ \\
\hline
\end{tabular}

* Standard error of the mean.

† Obtained from the propagation of error formula for a quotient of two random variables (E. B. Wilson, An Introduction to Scientific Research, McGraw Hill, 1952). 
to insulin in quantities up to 50 or 100 per cent by weight were without effect on the assay of insulin by either the mouse or the rabbit methods. Because of the short duration of the hyperglycemia caused by glucagon, its effect has disappeared before the insulin hypoglycemia was well established. Root (18) has found that administration of large amounts of highly purified glucagon over long periods to rats and rabbits does not cause any pathological changes. Furthermore, no permanent nor lasting alteration of the blood sugar level was observed. On the basis of these experiments it appears that glucagon has no significant influence on the hypoglycemic activity of insulin. Similarly there is no evidence that glucagon elicits undesirable side effects.

\section{SUMMARY}

The hyperglycemic factor content of some crystalline insulin samples has been determined on a quantitative basis. The crystalline $\mathrm{Zn}$-insulin preparations contained 0.3 to 0.5 per cent of the factor. The effect of glucagon in insulin preparations is discussed.

\section{REFERENCES}

1. Kimball, C. P., and Murlin, J. R., Aqueous extracts of pancreas. III. Some precipitation reactions of insulin. J. Biol. Chem., 1923, 58, 337.

2. Nielsen, N. A., Die Wirkung des Insulins auf den Glykogengehalt der perfundierten kaninehenleber. Biochem. Ztschr., 1931, 230, 259.

3. Bürger, M., Das Glukagon. Fortschr. diagn. u. therap., 1950, 1, 225.

4. Conn, J. W., Endocrine regulation of the blood sugar. Ann. Int. Med., 1953, 38, 179.
5. Staub, A., Sinn, L., and Behrens, O. K., Purification and crystallization of hyperglycemic glycogenolytic factor (HGF). Science, 1953, 117, 628.

6. Staub, A., Sinn, L., and Behrens, O. K., Characterization of glucagon (hyperglycemic-glycogenolytic factor). Federation Proc., 1954, 13, 303.

7. Bürger, M., and Brandt, W., Uber das Glukagon (Die Hyperglykämisierende Substanz des Pankreas). Ztschr. f. d. ges. exper. Med., 1935, 96, 375.

8. Fredericq, E., and Neurath, H., The interaction of insulin with thiocyanate and other anions. The minimum molecular weight of insulin. J. Am. Chem. Soc., 1950, 72, 2684.

9. Harfenist, E. J., and Craig, L. C., Countercurrent distribution studies with insulin. J. Am. Chem. Soc., 1952, 74, 3083.

10. Sutherland, E. W., Cori, C. F., Haynes, R., and Olsen, N. S., Purification of the hyperglycemicglycogenolytic factor from insulin and from gastric mucosa. J. Biol. Chem., 1949, 180, 825.

11. Timasheff, S. N., Brown, R. A., and Kirkwood, J. G., The fractionation of insulin by electrophoresisconvection. J. Am. Chem. Soc., 1953, 75, 3121.

12. Weitzel, G., Fretzdorff, A. M., Strecker, F. J., and Rcester, U., Zinkgehalt und Glukagoneffekt Kristallisierter Insulinpräparate. Ztschr. f. physiol. Chem., 1953, 293, 190.

13. Porter, R. R., Partition chromatography of insulin and other proteins. Biochem. J., 1953, 53, 320.

14. Mohnike, G., and Boser, H., Ein HyperglykämisierendGlykogenolytisches Pankreasnucleoproteid. Ztschr. f. d. ges. exper. Med., 1954, 123, 415.

15. Olsen, N. S., and Klein, J. R., Hyperglycemia induced by certain insulin preparations. Proc. Soc. Exper. Biol. \& Med., 1947, 66, 86.

16. Somogyi, M., A reagent for the copper-iodometric determination of very small amounts of sugar. J. Biol. Chem., 1937, 117, 771.

17. Root, M. A., Ellis, J., and Staub, A., Effect of glucagon on insulin hypoglycemia. Proc. Soc. Exper. Biol. \& Med., 1954, 85, 507.

18. Root, M. A., Proc. Soc. Exper. Biol. \& Med., In press. 